Pierre Marie MAPongmetsem ${ }^{1}$ Guidawa FAWA ${ }^{1}$

Jean Baptiste NoubISSIE-TCHIAGAM ${ }^{1}$ Bernard Aloys NKONG MENECK ${ }^{2}$ S.S. Honoré BIAOU Ronald BELLEFONTAINE ${ }^{4}$

${ }^{1}$ University of Ngaoundere Department of Biological Sciences P. O. Box 454

Ngaoundere

Cameroon

${ }^{2}$ University of Yaounde I Department of Plant Biology B.P. 812, Yaounde

Cameroon

3 University of Parakou Faculty of Agronomy Parakou

Benin

${ }^{4}$ CIRAD

UMR AGAP

34398 Montpellier Cedex 5 France

\title{
Vegetative propagation of Vitex doniana Sweet from root segments cuttings
}

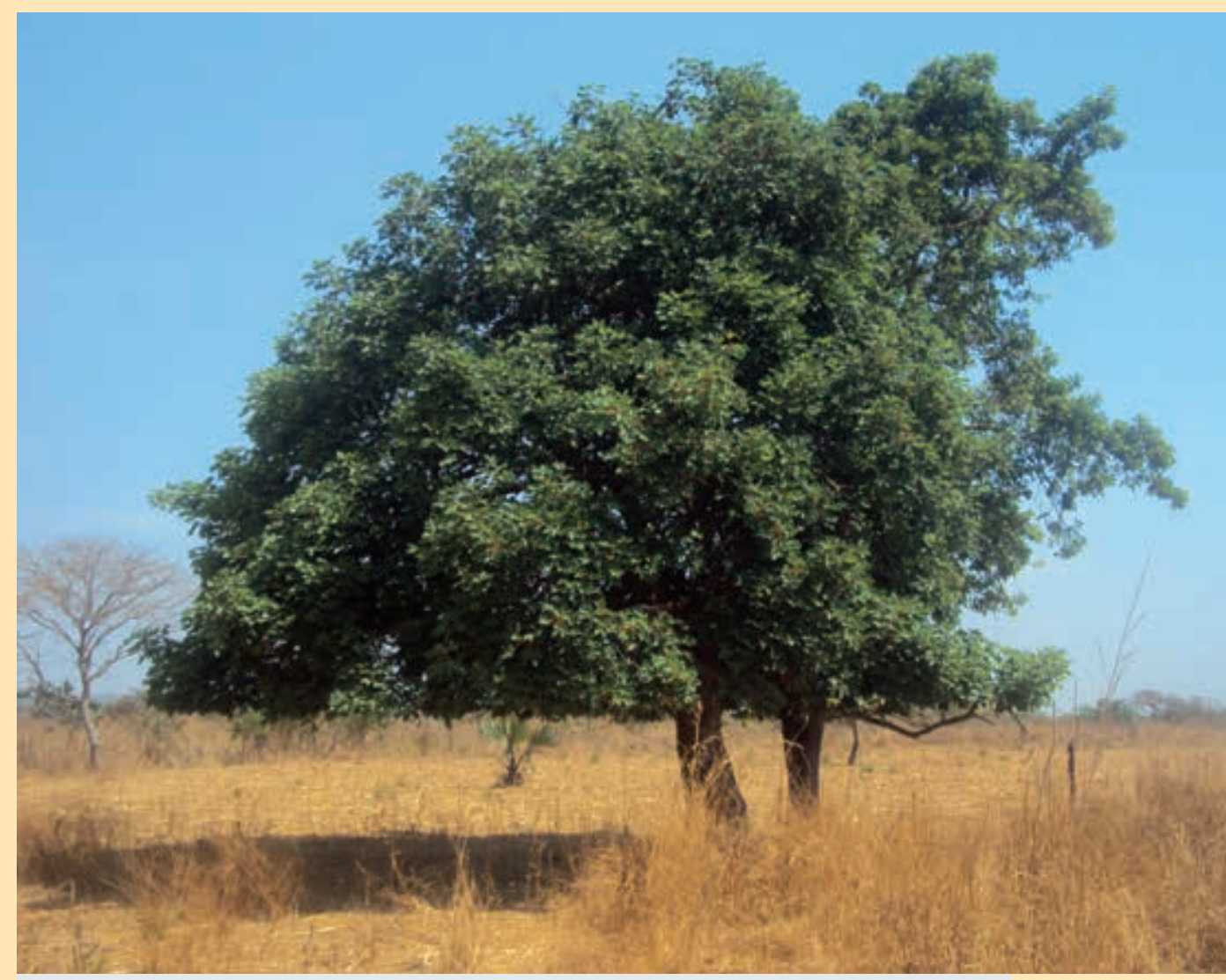

Photo 1.

Vitex doniana trees in the pasture.

Photo P. M. Mapongmetsem. 


\section{P. M. Mapongmetsem, G. FaWA, J. B. NOUBISSIE-TCHIAGAM, \\ B. A. NKongmenecK, \\ S. S. H. Biaou, R. Bellefontaine}

\section{RÉSUMÉ}

\section{PROPAGATION VÉGÉTATIVE DE VITEX DONIANA SWEET À PARTIR DE SECTIONS DE RACINE}

Vitex doniana Sweet est une espèce à usages multiples d'une grande importance socio-économique et commune en Afrique tropicale. Malgré sa forte utilisation en milieu rural, elle est encore présente à l'état sauvage. Il existe peu de données sur sa domestication. La propagation de cet arbre par bouturage de segments de racine constitue une alternative à sa difficile régénération sexuée. L'objectif de notre travail était d'évaluer deux des facteurs clés (substrat d'enracinement, diamètre des boutures) qui influencent l'aptitude des boutures de segments de racine (BSR) à néoformer des pousses feuillées et des racines. Le système racinaire de 23 arbres a été partiellement excavé sur une profondeur de $20 \mathrm{~cm}$. Des BSR de $15 \mathrm{~cm}$ de long ont été disposées horizontalement dans des polypropagateurs sur cinq substrats différents, arrosés matin et soir. Le dispositif était un split-plot à trois répétitions. Le traitement principal recouvrait cinq substrats : terre noire (Tn), sable fin (S), sciure de bois (Sc), 50 \% Tn/50 \% Sc (Tn$\mathrm{Sc}$ ) et $50 \% \mathrm{Tn} / 50 \% \mathrm{~S}$ (Tn-S). Le traitement secondaire distinguait deux classes de diamètre $(0,5-1 \mathrm{~cm} ; 1,1-2,5 \mathrm{~cm})$. Après la mise en culture des BSR, le temps de latence d'émergence était de 8 semaines pour les pousses aériennes et 12 pour les racines. Après 28 semaines, le pourcentage de pousses feuillées formées variait de $28 \%$ (Tn) à $55 \%$ (S). Les pousses aériennes se sont développées majoritairement (82 \%) sur le pôle distal. Le diamètre des BSR a déterminé le développement des pousses feuillées $(P<0,01)$. Le taux de bourgeonnement des BSR oscillait entre $21,0 \pm 1,8 \%$ pour les BSR de 0,5 $1 \mathrm{~cm}$ et $86,0 \pm 7,8 \%$ pour la classe $1,1-2,5 \mathrm{~cm}$. Le diamètre a également impacté l'enracinement des BSR $(P<0,001)$. Le taux d'enracinement des BSR variait de $12,0 \pm 2,3 \%$ pour les petits diamètres à $59,3 \pm 4,7 \%$ pour les plus gros. La multiplication végétative par BSR peut améliorer la filière économique de $V$. doniana dans les hautes savanes guinéennes du Cameroun.

Mots-clés : Vitex doniana, multiplication végétative, domestication, aptitude à l'enracinement, bouturage de segments de racine, Cameroun.

\section{ABSTRACT}

\section{RESUMEN}

\section{VEGETATIVE PROPAGATION OF VITEX DONIANA SWEET FROM ROOT SEGMENT CUTTINGS}

Vitex doniana Sweet is a common multipurpose species in tropical Africa, which has considerable socio-economic importance. Unfortunately, it is extracted from the wild and there has been little or no focused effort to domesticate and cultivate the species. Mastering its propagation through root segment cuttings (RSC) is a real alternative to the difficult process of regeneration from seeds. The aim of our study was to assess two of the key factors (rooting medium and root diameter) that influence its rooting ability. The root system of 23 trees was partially excavated to a depth of $20 \mathrm{~cm}$. Root segment cuttings $15 \mathrm{~cm}$ in length were carefully cut and arranged horizontally in a polypropagator, on five different substrates. The experimental setup involved a split-plot design with three replications. The main treatment was applied to all five substrates: black soil (Bs), fine sand (S), sawdust (Sd), 50\% Bs/50\% Sc (Bs-Sc) and 50\% Bs:50\% S (Bs-S). The secondary treatment covered two diameter size classes $(0.5-1 \mathrm{~cm} ; 1.1-2.5 \mathrm{~cm})$. The latency time before emergence was 8 weeks for the aerial shoots and 12 weeks for the roots. After 28 weeks, the percentage of leafy shoots formed varied from $28.3 \%$ in the black soil substrate (Bs) to $55.0 \%$ in the sand (S). Aerial shoots developed mainly $(82 \%)$ on the distal pole. The RSC diameter had a significant influence $(P<0.01)$ on the development of leafy shoots. The budding rate of the RSC was $21 \pm 1.8 \%$ for $0.5-1 \mathrm{~cm}$ RSC and $86 \pm 7.8 \%$ for $1.1-2.5 \mathrm{~cm}$ RSC. The diameter also had a significant impact $(P<0.001)$ on RSC rooting. The rooting rate was $12 \pm 2.3 \%$ for $0.5-1 \mathrm{~cm}$ RSC and $59.3 \pm 4.7 \%$ for $1.1-2.5 \mathrm{~cm}$ RSC. These results show that vegetative propagation by RSC could improve the economic value of V. doniana in Cameroon's savannah uplands.

Keywords: Vitex doniana, vegetative propagation, domestication, rooting ability, root segment cuttings, Cameroon.

\section{PROPAGACIÓN VEGETATIVA DE VITEX DONIANA SWEET POR SEGMENTOS DE RAIIZ}

Vitex doniana Sweet es una especie de usos múltiples bastante común en África tropical y de gran importancia socioeconómica. Aunque se usa mucho en zonas rurales, aún se emplean plantas silvestres y existen pocos datos sobre su domesticación. La propagación de este árbol mediante estaquillado de segmentos de raíz es una alternativa a la difícil regeneración sexual. El objetivo de nuestro estudio fue evaluar dos factores clave (sustratos de enraizamiento y diámetro de estaquillas) que influyen en la capacidad de las estaquillas de segmentos de raíz (ESR) para generar nuevos brotes con hojas y raíces. Se excavó parcialmente el sistema radicular de 23 árboles hasta una profundidad de $20 \mathrm{~cm}$. Se colocaron horizontalmente ESR de $15 \mathrm{~cm}$ de longitud en polipropagadores, en cinco sustratos distintos con riego mañana y tarde. Se empleó un diseño por parcelas subdivididas con tres repeticiones. El tratamiento principal incluía los cinco sustratos: tierra negra ( $\mathrm{Tn})$, arena fina (A), serrín de madera (Sm), 50\% Tn/50\% $\mathrm{Sm}$ (Tn-Sm) y 50\% Tn/50\% A (Tn-A). El tratamiento secundario diferenciaba dos clases de diámetro (0,5-1cm; 1,1-2,5 cm). Tras la siembra de los ESR, el tiempo de latencia para la emisión fue de 8 semanas para los brotes aéreos y de 12 para las raíces. Después de 28 semanas, el porcentaje de brotes con hojas formadas variaba de $28 \%(\mathrm{Tn})$ a $55 \%$ (A). Los brotes aéreos se desarrollaron principalmente (82\%) en el extremo distal. El diámetro de las ESR determinó el desarrollo de los brotes con hojas $(P<0,01)$. La tasa de brotación de las ESR varió entre $21,0 \pm 1,8 \%$ en las ESR de $0,5-1 \mathrm{~cm}$ y $86,0 \pm 7,8 \%$ en las de 1,1-2,5 cm. El diámetro también afectó significativamente al enraizamiento de las ESR ( $P<0,001)$. La tasa de enraizamiento de las ESR varió de $12,0 \pm 2,3 \%$ en los diámetros pequeños a $59,3 \pm 4,7 \%$ en los mayores. La multiplicación vegetativa por ESR puede mejorar el sector económico de $V$. doniana en las altas sabanas de clima guineano de Camerún.

Palabras clave: Vitex doniana, multiplicación vegetativa, domesticación, capacidad para el enraizamiento, estaquillado de segmentos de raíz, Camerún. 


\section{Introduction}

The African savannas' black plum (Vitex doniana Sweet) is a multipurpose Verbenaceae species widespread in tropical Africa, commonly found from Senegal to Cameroon and Somalia as well as in Central Africa. It is of great socioeconomic interest (Wala et al., 2009; Oladele, 2011), mainly for its extensively documented food and medicinal properties. The fruits are eaten (Mapongmetsem et al., 2012a; KranjacBerisavljevic and Gandaa, 2013) or used for juices and jams (Ajenifujah-Solebo and Aina, 2011). Leaves and fruits are sold on local and regional markets (Mapongmetsem et al., 2012a). Young leaves (eaten as spinach) and barks are used in the treatment of several human diseases (Okafor, 1991; Sanogo et al., 2009; Amegbor et al., 2012; Ouattara et al., 2013; KranjacBerisavljevic and Gandaa, 2013; Adetoro et al., 2013; Ochieng et al., 2013) as well as animal diseases (Suleiman and Yusuf, 2008; Tijjani et al., 2012; Njidda, 2012). In addition, there is a great variability in the fruit organoleptic and morphological characteristics according to the local people of the Northern Cameroon. This Verbenaceae has numerous utilisations with promising economic potential for poverty alleviation in rural and peri-urban areas in Africa.

Sustainability of forest resources exploitation relies on a good balance between social, economic and environmental parameters. In the upper Guinean savannas of Cameroon, the vegetation is degraded and natural ecosystems are weakened; $V$. doniana, one of the major multipurpose tree species is threatened with extinction locally, as in Ghana (Kranjac-Berisavljevic and Gandaa, 2013) and Benin (Sanoussi et al., 2012). The high utilization pressure on the species combined with the low regeneration ability cause a steady depletion of natural populations, while no clear and straightforward conservation strategies have been developed neither at community level nor at national level. As the living conditions of populations in underdeveloped and developed countries are becoming increasingly precarious, local fruits could play an important role in improving nutritional conditions and livelihoods of these populations (Tchiegang-Megueni et al., 2001; Kristensen and Lykke, 2003; Mapongmetsem et al., 2008; Oladele, 2011; N'danikou et al., 2011; Dadjo et al., 2012; Sanoussi et al., 2012). Yet, farmers attempted regeneration of $V$. doniana but faced constraints related to seed dormancy and long growing period, which resulted overall in very poor results (Thies, 1995; Sanoussi et al., 2012). Other methods of regeneration must be explored in order to propose appropriate solutions for the conservation of the tree species, highly demanded by local populations, and to allow its reintroduction into farmers' production systems (Mapongmetsem et al., 2012a; Meunier et al., 2006). Despite the importance of the species in Africa, little scientific research has been devoted to its regeneration, except for studies related to stem cuttings carried by Mapongmetsem et al. (2012b) and Sanoussi et al. (2012) which revealed a regeneration rate of 40-50.7\% attributed to samples origin and environmental conditions among other factors. $V$. doniana is a species that emits suckers (Thies, 1995; Bellefontaine, 2005; Oumorou et al., 2010) and, as many suckering species, it seems easy to obtain clones of selected V. doniana (Bellefontaine, 2005) through root segments cuttings (RSC). To promote a sustainable domestication of the species in developing countries, this extremely cheap and easy method allows rural people to maintain in their field or near their home a copy of an exceptional tree that fits with their standards (Meunier et al., 2006). Thus, mastering of vegetative propagation by RSC can bring real satisfaction to local communities and enable them to stabilize their favorite tree characters. This technique requires very few tools and almost no training for rural people (Ruchala, 2002; Bellefontaine, 2005; Beyl, 2008; Meunier et al., 2008; Ky-Dembélé et al., 2010; Bellefontaine, 2010; Sanoussi et al., 2012). RSC is currently the most suitable tool to propagate elite trees with advantageous phenotypic and genotypic characters (Nsibi et al., 2003; Stenvall et al., 2005 and 2006). In order to meet this need, this study aimed at assessing the possibilities of growing black plum tree plants from root segments cuttings. The lack of data on the factors controlling the ability of RSC to form leafy shoots and roots is a major handicap for the promotion of this technique. Here it is hypothesized that substrate and cutting diameter are among the key factors that affect the regeneration capacity of the material and the overall ability to grow.

\section{Materials and methods}

\section{Study area}

Root segments used in the study were sampled in Guinean Savannah Highlands of Adamawa. This region is characterized by a Guinean climate, with two seasons: a rainy season from April to October and a dry season from November to March. For the period 2000-2012, the average annual rainfall was $1,447 \mathrm{~mm}$, the average annual temperature $22.3^{\circ} \mathrm{C}$, the average annual relative humidity $67 \%$ and the average annual evaporation $1,645 \mathrm{~mm}$. The region is delimited by two boundaries: the Sudanese savannas in the north and the semi-deciduous Guinean vegetation in the south. The area is covered with shrubland and / or tree savannah dominated by Daniellia oliveri and Lophira lanceolata (Letouzey, 1968). The evolution of the vegetation is severely hampered by human impacts (Ibrahima et al., 2006).

\section{Preparation and cultivation of root segments cuttings}

The experiment was conducted at the nursery of the University of Ngaoundere during 28 weeks, from February 8 to August 25, 2012. Plant material used in the experiment was collected from superficial roots of 23 adult $V$. doniana trees of $\mathrm{dbh}>50 \mathrm{~cm}$. These genotypes were selected in the BiniDang upper Guinean savannas (altitude $1081 \mathrm{~m}, 13^{\circ} 33^{\prime} 130^{\prime \prime}$ East, $7^{\circ} 25^{\prime} 127^{\prime \prime}$ North). Preferred characteristics of local populations were considered in the selection of the parent trees: good sanitary condition, large fruits, regular production and low branching. After partial excavation to a depth of $20 \mathrm{~cm}$, the root segments were collected using a pruner, then wrapped in a moistened newsprint paper and transported in 
a cooler to the nursery. Upon arrival at the nursery on the same day, the root segments were cut into $15 \mathrm{~cm}$ long root segments cuttings (RSC) and divided into two size classes: $0.5-1 \mathrm{~cm}$ and $1.1-2.5 \mathrm{~cm}$; then inserted in rooting media. A $1 \mathrm{~cm}$ notch was made at the distal end of each RSC (Ky-Dembélé et al., 2010).

A total of 300 RSC were obtained and arranged horizontally within $3 \mathrm{~cm}$ of substrate in a non-mist propagator (Leakey et al., 1990). A non-mist propagator is a wooden frame enclosed in a single sheet of polythene such that the base is completely water tight. The frame was covered tightly with a single piece polythene and a closely-fitting lid. It was $3 \mathrm{~m}$ long versus $1 \mathrm{~m}$ wide and $1 \mathrm{~m}$ height at the back and $0.5 \mathrm{~m}$ in the main façade. The polypropagator was divided in three equal compartments thus corresponding to three replications. The polythene base of the propagator was covered with a thin layer of sand to protect the polythene and large stones were placed on top of the sand to a depth of $10-15 \mathrm{~cm}$. This was then covered by successive layers of small stones and gravel to a total depth of $20 \mathrm{~cm}$. The spaces between stones and gravel were filled with water. The saturated layers of stones and gravel were covered by five rooting medium: sawdust (Sd), sand (S), black soil (Bs), and two 50/50\% homogeneous mixtures of black soil-sawdust (Bs-Sd) and black soil-sand (Bs-S). The rooting medium remained moist by capillarity and could be dampened from the above as necessary. This resulted in a permanently humid environment throughout the propagation period. The RSC were watered twice a day (morning and evening) using a hand sprayer. An open cylinder made of PVC pipe was inserted vertically into the medium and stones. This pipe was used as the filling point for the water and allowed a regular check of the water table. Temperature within the polypropagator was $28-30{ }^{\circ} \mathrm{C}$ while the humidity was around $85-90 \%$ after watering. Starting from the end of the eighth week, corresponding to the first appearance of leafy shoots, a systematic inventory was conducted weekly to assess the number of RSC that emit one or more leafy shoots, the number of leafy shoots and the number of leaves per shoot. Regarding rooting, the RSC with one or more leafy shoots were meticulously excavated each week and the presence of new roots noted. Unrooted cuttings were reintroduced into the substrate. A root segment cutting with at least one leaf was considered budded. A cutting was considered as rooted if the length of the root was greater than $1 \mathrm{~cm}$ (Mapongmetsem et al., 2012b). Rooted cuttings were inserted horizontally in large perforated polyethylene bags $(27 \mathrm{~cm}$ diameter $\times 40 \mathrm{~cm}$ height) containing the black soil-sawdust which was found performant by the authors. These bags were introduced in acclimatization propagators and watered mornings and evenings. During the acclimatization phase, the propagators were left open each night during a month. Watering was then reduced to once a day. After this acclimatization phase, the plants were transferred to the field.

\section{Experimental design and data analysis}

The experimental design was a split-plot design with three replications. The substrate was the main treatment with five modalities, while the diameter with two classes represented the secondary treatment. The experimental unit consisted of 10 cuttings and the 23 genotypes were not tested separately. They were distributed in treatments and repetitions at random. The following parameters were determined:

a) The rate of budding, the number of leafy shoots per RSC, the height and number of leaves of each leafy shoot. Budding corresponds to bud burst of latent buds that emit one or more leafy shoots on the RSC.

b) The rate of rooting (equated to the success rate of the RSC), the pole on which the leafy shoots have developed (distal or proximal pole), the number and length of the roots. The distal pole corresponds to the extremity of the RSC which was originally located farthest from the base of the parent tree.

Quantitative data were subjected to an analysis of variance (ANOVA) and post-hoc comparisons were done with the Duncan's Multiple Range Test (DMRT) when significant main effects were detected. All the analyses have been performed using the Statgraphics 5.0 software.

\section{Results}

\section{Effect of the substrate and the diameter of RSC on leafy shoots formation}

\section{Rate of budding}

The first leafy shoots were observed at the beginning of the $8^{\text {th }}$ week for cuttings of $1.1-2.5 \mathrm{~cm}$ diameter (large diameters), and at the beginning of the $11^{\text {th }}$ week for cuttings of $0.5^{-1} \mathrm{~cm}$ diameter (small diameter). The rate of budding at the end of the essay ( $28^{\text {th }}$ week), was between $28.3 \%$ in the black soil and $55 \%$ in the sand (table I). Although the differences between the substrates were not significant $(P>0.05)$, the top performing substrates were: sand (55\%) and the mixture black soil-sawdust (51.7\%), followed by sawdust (36.7\%). The worst performing substrates were the black soil (28.3\%) and the mixture black soil-sand soil (30\%).

In contrast, the diameter of the cuttings had a significant effect on the budding rate $(P<0.001)$. In the beginning $\left(8^{\text {th }}\right.$ week), the budding rate was o \% for RSC of $0.5-1 \mathrm{~cm}$ diameter and $2 \%$ for $1.1-2.5 \mathrm{~cm}$ diameter whereas at the end of the experiment ( $28^{\text {th }}$ week), it was $21 \pm 1.82 \%$ for the $0.5-1 \mathrm{~cm}$ diameter RSC and $86 \pm 7.85 \%$ for the $1.1-2.5 \mathrm{~cm}$ diameter RSC.

\section{Number of leafy shoots per RSC}

By the end of the experiment (after 28 weeks), the average number of leafy shoots ranged from $0.7 \pm 0.5$ in the mixture Bs-S to $1.9 \pm 0.7$ in Bs-Sd (table I). However, there were no significant differences between the substrates $(P>0.05)$. On the contrary, the RSC diameter had a significant effect $(P<0.01)$ on leafy shoots formation. The average number of leafy shoots was $1.3 \pm 0.6$ for the $0.5-1 \mathrm{~cm}$ diameter RSC and $10.9 \pm 1.3$ for the $1.1-2.5 \mathrm{~cm}$ diameter RSC (table II). 
Table I.

Effect of the substrate on leafy shoots formation after 28 weeks.

\begin{tabular}{|l|c|c|c|c|c|}
\hline Growth parameters & $\begin{array}{c}\text { Black soil } \\
\text { (Bs) }\end{array}$ & $\begin{array}{c}\text { Black soil-Sawdust } \\
\text { (Bs-Sd) }\end{array}$ & Sand (S) & $\begin{array}{c}\text { Black soil-Sand } \\
\text { (Bs-S) }\end{array}$ & $\begin{array}{c}\text { Sawdust } \\
\text { (Sd) }\end{array}$ \\
\hline $\begin{array}{l}\text { Total number (and percentage) } \\
\text { of RSC having formed a minimum } \\
\text { of one aerial shoot }\end{array}$ & $\begin{array}{c}17 \\
(28.3 \%)\end{array}$ & $\begin{array}{c}31 \\
(51.7 \%)\end{array}$ & $\begin{array}{c}33 \\
(55.0 \%)\end{array}$ & $\begin{array}{c}18 \\
(30.0 \%)\end{array}$ \\
\hline $\begin{array}{l}\text { Average number of leafy shoots } \\
\text { per RSC }\end{array}$ & $1.4 \pm 1.0$ & $2.0 \pm 0.7$ & $1.7 \pm 0.0$ & $0.7 \pm 0.5$ & $1.7 \pm 0.7$ \\
\hline $\begin{array}{l}\text { Average height of leafy shoots } \\
\text { (cm) }\end{array}$ & $3.4 \pm 2.8$ & $3.4 \pm 2.3$ & $3.8 \pm 1.6$ & $2.1 \pm 1.5$ & $4.6 \pm 0.2$ \\
\hline $\begin{array}{l}\text { Average number of leaves } \\
\text { per leafy shoot }\end{array}$ & $4.0 \pm 3.0$ & $5.3 \pm 4.6$ & $4.9 \pm 2.5$ & $3.6 \pm 2.9$ & $6.5 \pm 2.6$ \\
\hline
\end{tabular}

Table II.

Effect of the RSC diameter on leafy shoots formation after 28 weeks.

\begin{tabular}{|l|c|c|c|c|}
\hline RSC diameter (cm) & Rate of budding (\%) & $\begin{array}{c}\text { Average number of } \\
\text { leafy shoots }\end{array}$ & $\begin{array}{c}\text { Average height of } \\
\text { the leafy shoots (cm) }\end{array}$ & $\begin{array}{c}\text { Average number of } \\
\text { leaves per leafy shoot }\end{array}$ \\
\hline $0.5-1$ & $21.0 \mathrm{~b}$ & $1.3 \pm 0.6 \mathrm{~b}$ & $1.8 \pm 0.5 \mathrm{~b}$ & $1.8 \pm 0.5 \mathrm{~b}$ \\
\hline $1,1-2,5$ & $86.0 \mathrm{a}$ & $10.9 \pm 1.3 \mathrm{a}$ & $5.1 \pm 2.9 \mathrm{a}$ & $9.4 \pm 2.8 \mathrm{a}$ \\
\hline Overall mean & 54 & $6.1 \pm 1.0$ & $3.5 \pm 1.7$ & $5.6 \pm 1.7$ \\
\hline
\end{tabular}

Note: Means followed by different letters for a given growth parameter are statistically different at $\mathrm{P}<0.05$.

\section{Height of the leafy shoots and number of leaves per leafy shoot}

At the end of the experiment ( $28^{\text {th }}$ week), the average height of leafy shoots ranged from $2.1 \pm 1.5 \mathrm{~cm}$ in the mixture Bs-S to $4.6 \pm 0.1 \mathrm{~cm}$ in sawdust (table II). Despite the observed variability, the substrate had no significant effect $(P>0.05)$, whereas the diameter of the RSC had a significant effect on the height of leafy shoots $(P<0.01)$. The average height was $1.8 \pm 0.5 \mathrm{~cm}$ for the $0.5-1 \mathrm{~cm}$ diameter RSC and $5.1 \pm 2.9 \mathrm{~cm}$ for the 1.1-2.5 cm diameter RSC (table II).

At the $28^{\text {th }}$ week, the average number of leaves per leafy shoot varied from $3.6 \pm 2.9$ in the mixture Bs-S to $6.5 \pm 2.6$ in sawdust (table I). However there was no significant difference between the substrates $(P>0.05)$.

In contrast, the effect of the RSC diameter on the number of leaves per leafy shoot was significant $(P<0.01)$. The average number of leaves per leafy shoot was $1.8 \pm 0.5$ for the $0.5-1 \mathrm{~cm}$ diameter RSC and $9.4 \pm 2.8$ for the $1.1-2.5 \mathrm{~cm}$ diameter RSC (table II).

The interaction substrate-RSC diameter was not significant on the number of leafy shoots $(P>0.05)$, the average height of leafy shoots $(P>0.05)$, nor the number of leaves per leafy shoot $(P>0.05)$.

Both the maximum average height $(6.7 \pm 2.3 \mathrm{~cm})$ of the leafy shoots and the maximum number of leaves per leafy shoot $(11.8 \pm 4.7 \mathrm{~cm})$ were reached with the $1.1-2.5 \mathrm{~cm}$ diameter RSC in the sawdust.

\section{Location of the leafy shoots formation}

The leafy shoots developed at different locations on the RSC inserted horizontally: $9 \%$ on the proximal pole, $5 \%$ on the middle section, $2 \%$ middle-distal and $82 \%$ on the distal pole. In the case of disto-proximal location ( $2 \%$ ), shoots appeared both in distal and proximal poles (photo $1 b$ ). Furthermore, the morphology of the first leaves (simple with only one lobe) was different from the mature leaves which are digitated.

\section{Effect of the substrate and the diameter of RSC on root formation}

\section{Rate of rooting}

The formation of adventitious roots began on the $12^{\text {th }}$ week after the start of the experiment on the 1.1-2.5 cm diameter RSC in the sawdust. The rooting rate of the RSC varied significantly ( $P<0.001$ ) from $12 \pm 2.3 \%$ for the $0.5-1 \mathrm{~cm}$ diameter RSC to $59.33 \pm 4.67 \%$ for the $1.1-2.5 \mathrm{~cm}$ diameter RSC. The RSC have often developed a dense root system with long roots (photo 2). Generally, roots appeared both on the distal and proximal poles of the RSC with predominance on the distal one.

The overall average rooting rate was $60.7 \%$ across substrates but the best rooting rate was observed in the sand (83.3\%) and the mixture Bs-Sd (90\%) (table III). However, the substrate did not affect significantly the rooting $(P>0.05)$. The number of roots and their length were evaluated. 


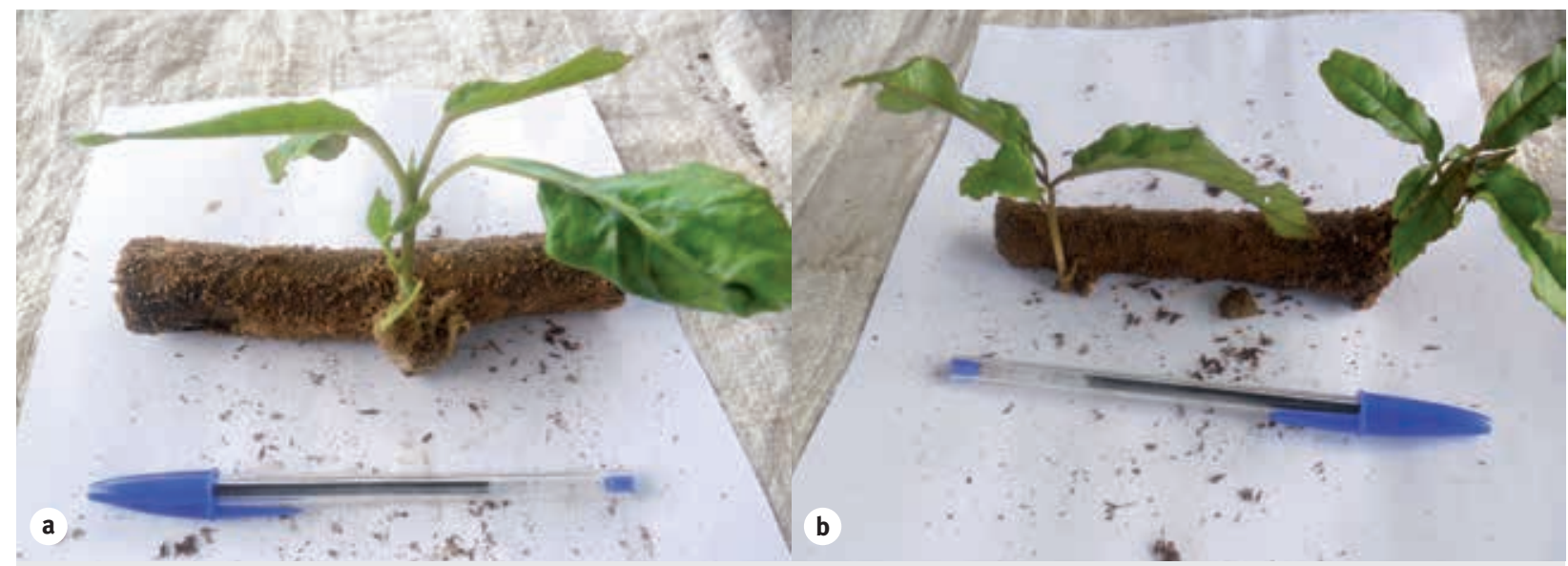

Photo 1.

Leafy shoots formed at the median section (a), distal pole (b, left side of the RSC) and proximal pole (b; right side of the RSC) of a 1.1-2.5 $\mathrm{cm}$ diameter RSC after 28 weeks.

Photos P. M. Mapongmetsem.

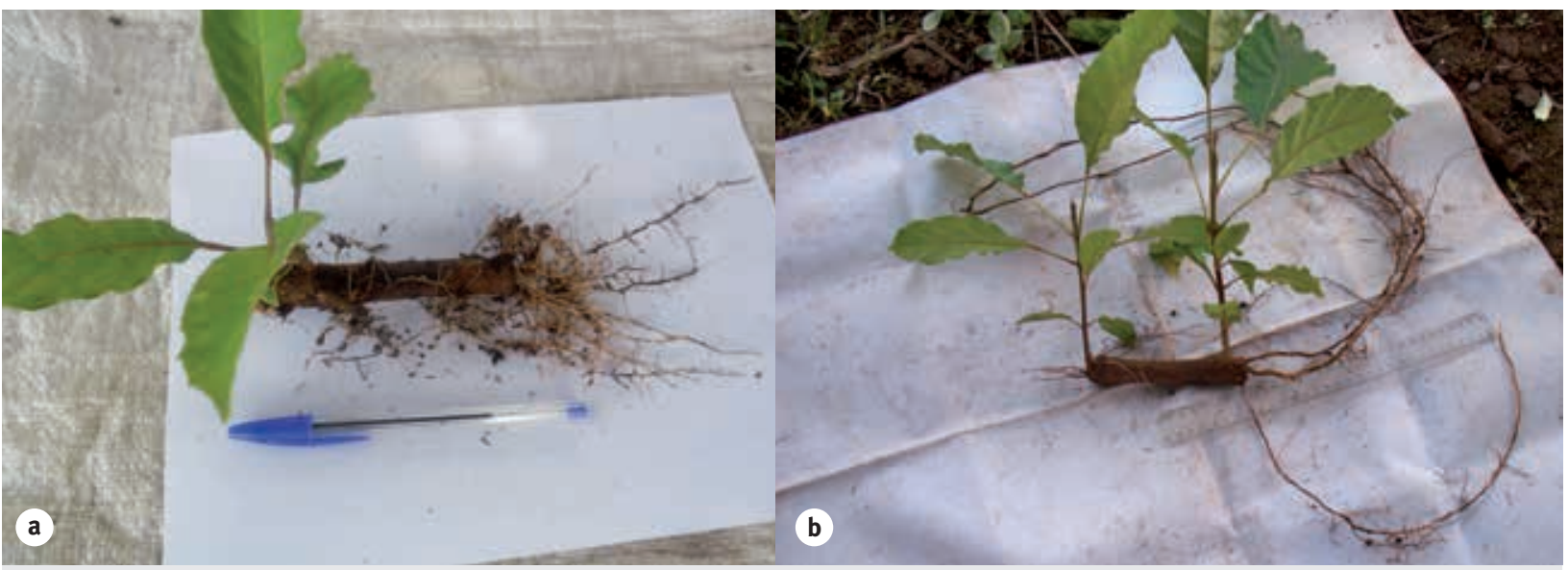

Photo 2.

Rooted RSC of 18 and 20 weeks with developed roots and presenting one (a) and two leafy shoots (b) after 28 weeks.

Photos P. M. Mapongmetsem.

\section{Average number and length of RSC roots}

At the end of the experiment (week 28), the average number of roots per RSC varied from $4.3 \pm 1.4$ in the black soil-sand mixture to $8.2 \pm 3.5$ in the sawdust. There was however no significant difference between the substract $(P>0.05)$.

The diameter of the RSC had a significant effect on the number of roots formed $(P<0.001)$ and the maximum number of roots $(10.5 \pm 1.5)$ was recorded for the 1.1-2.5 cm diameter RSC (table IV).

Roots of shorter length $(79.3 \pm 65.7 \mathrm{~mm})$ were observed in the black soil, while the longest roots developed in the sand $(221.8 \pm 198.2 \mathrm{~mm})$ and the sawdust $(243.5 \pm 28.2 \mathrm{~mm}$ ) (table III). However, there were no significant differences between the substrates $(P>0.05)$.
On the other hand, the diameter of the RSC had a significant effect $(P<0.001)$ on root length. The average root length was $50.5 \pm 15.3 \mathrm{~mm}$ for the $0.5-1 \mathrm{~cm}$ diameter RSC and $301.6 \pm 50.3 \mathrm{~mm}$ for the $1.1-2.5 \mathrm{~cm}$ diameter RSC (table IV). The interaction substrate-RSC diameter was not significant for the number of adventitious roots $(P>0.05)$, nor their length $(P>0.05)$. Nethertheless, there was no root formation for the $0.5-1 \mathrm{~cm}$ diameter RSC in the black soil-sand mixture, while the average number of roots and the average length of the root were highest in the sawdust and sand substrates.

Like leafy shoots, roots appear generally on the distal pole of RSC whereas in the case of disto-proximal shoots, both sections rooted (photo 2 b). 
Table III.

Effect of the substrate on the RSC root formation after 28 weeks.

\begin{tabular}{|c|c|c|c|c|c|c|}
\hline $\begin{array}{l}\text { Parameters } \\
\text { after } \mathbf{2 8} \text { weeks }\end{array}$ & $\begin{array}{l}\text { Black soil } \\
\text { (Bs) }\end{array}$ & $\begin{array}{c}\text { Black soil- } \\
\text { sawdust (Bs-Sd) }\end{array}$ & Sand (S) & $\begin{array}{c}\text { Black soil-sand } \\
\text { (Bs-S) }\end{array}$ & Sawdust (Sd) & $\begin{array}{l}\text { Black soil } \\
\text { (Bs) }\end{array}$ \\
\hline Rooting rate (\%) & 36.7 & 90.0 & $83 \cdot 3$ & $43 \cdot 3$ & 50.0 & 60.7 \\
\hline $\begin{array}{l}\text { Average number } \\
\text { of roots per RSC }\end{array}$ & $5.0 \pm 3.9$ & $6.7 \pm 5.8$ & $8.0 \pm 7.9$ & $4 \cdot 3 \pm 1.4$ & $8.2 \pm 3.5$ & $6.4 \pm 4.5$ \\
\hline $\begin{array}{l}\text { Average root } \\
\text { length }(\mathrm{mm})\end{array}$ & $79.3 \pm 65.7$ & $190.2 \pm 131.0$ & $221.8 \pm 198.2$ & $145.4 \pm 48.4$ & $243.5 \pm 28.2$ & $176.0 \pm 94 \cdot 3$ \\
\hline
\end{tabular}

Table IV.

Effect of the RSC diameter on root formation after 28 weeks.

\begin{tabular}{|l|c|c|c|}
\hline \multicolumn{1}{|l}{$\begin{array}{l}\text { RSC } \\
\text { diameter }\end{array}$} & \multicolumn{1}{c}{$\begin{array}{c}\text { Rooting rate } \\
\text { (\%) }\end{array}$} & \multicolumn{1}{c|}{$\begin{array}{c}\text { Average } \\
\text { number } \\
\text { of roots }\end{array}$} & $\begin{array}{c}\text { Average root } \\
\text { length (mm) }\end{array}$ \\
\hline $0.5-1 \mathrm{~cm}$ & $12.0 \pm 2.3 \mathrm{a}$ & $1.1 \pm 0.2 \mathrm{a}$ & $50.5 \pm 15 \cdot 3 \mathrm{a}$ \\
\hline $1.1-2.5 \mathrm{~cm}$ & $59.3 \pm 4.7 \mathrm{~b}$ & $10.5 \pm 1.5$ & $301.6 \pm 50.3 \mathrm{~b}$ \\
\hline $\begin{array}{l}\text { Overall } \\
\text { mean }\end{array}$ & $35.7 \pm 3.5$ & $5.8 \pm 0.9$ & $176.1 \pm 32.8$ \\
\hline
\end{tabular}

Note: Means followed by different letters for a given growth parameter are statistically different at $\mathrm{P}<0.05$.

\section{Discussion}

Aerial shoots on stems develop from axillary buds at the leaf axils, whereas branches form on roots from the inner initial cell mass produced by the dedifferentiation of pericambial cells which return to their meristematic state. The pericambial cells then redifferentiate and begin to split again, in the same way as cells in the apical meristem (Heller, 1985 cit. Sanoussi et al., 2012). This mechanism is responsible for the formation on the RSC of the first, morphologically simple, leaves. Budding and rooting of the RSC are separated in time. The separation of these two phenomena allows leafy shoots to supply adventitious roots with carbohydrates. Carbohydrates contribute to the formation of adventitious roots by supplying energy and carbon necessary for cell divisions, establishment of the new root meristems and root formation itself (da Costa et al., 2013). The formation of adventitious roots is more important than the development of aerial shoots, as the later could fade after a few days or weeks, if there is no newly formed root to feed the leafy shoots. The latency time of seven weeks for the formation of leafy shoots did not match the three weeks reported by Sanoussi et al. (2012) for the RSC of the same species in Benin. The difference between these results could be due to the diameter of parent trees, the genotype of the individuals or the season during which the cuttings have been sampled. In addition, the authors did not mention the diameter of the root cuttings used. The ability of a plant to propagate through RSC is regulated by several factors (endogenous, exogenous). It is maximal when the optimal combination of these factors is achieved.

In Finland, Stenvall et al. (2006) showed that for RSC of the hybrid Populus tremula $\times$ P. tremuloides, the rate of budding increased slightly (from 84.6 to $90.2 \%$ ) with the diameter, while the rooting rate (and thus the survival of the RSC) clearly decreased with diameter (from 34\% for diameters between $0.15-0.30 \mathrm{~cm}$ to $12 \%$ for larger diameters between $0.61-1 \mathrm{~cm}$ ), contrary to our observations on $V$. doniana. In line with our results, Ky-Dembélé et al. (2010) reported a rooting rate of $8 \%$ for Detarium microcarpum's cuttings of $1.1-2 \mathrm{~cm}$ diameter and $19 \%$ for cuttings of $2.1-4 \mathrm{~cm}$ diameter. Similarly, for Faidherbia albida, Harivel et al. (2006) obtained a rooting rate of $0 \%$ for $0.5 \mathrm{~cm}$ cuttings, and $30 \%$ and $47 \%$ for $1 \mathrm{~cm}$ and $1.5-2 \mathrm{~cm}$ cuttings, respectively.

In our experiment, the percentage of RSC that formed leafy shoots was $53.5 \pm 4.8 \%$ and increased with the RSC diameter. This rate is low compared with results from the hybrid poplar (Stenvall et al., 2006), but the experimental conditions were very different (diameter classes, soil temperature, species, season, genotypes, etc.). Unfortunately, there are very few trials with RSC in Africa to effectively compare results (but see Harivel et al., 2006; Ky-Dembélé et al., 2010; Sanoussi et al., 2012). In this experiment, the diameter of the RSC influenced significantly the formation of leafy shoots as well as roots. Overall, the success rate in the experiment was improved for larger diameters and this was particularly true for the number of leafy shoots, as well as their height and the number of leaves formed. Actually, $86 \%$ of the $1.1-2.5 \mathrm{~cm}$ diameter RSC produced leafy shoots while Harivel et al. (2006) obtained 47\% with $1.5-2 \mathrm{~cm}$ diameter for Faidherbia albida.

Regarding the substrates, no significant difference was found in this experiment regarding leafy shoots formation and roots formation of the RSC. These observations are consistent with results for the same species in Benin (Sanoussi et al., 2012) and for Brosimum gaudichaudii in Brazil (Silva et al., 2011).

In our experiment, the leafy shoots have emerged mainly on the distal pole while roots appeared both in distal and proximal poles. Stenvall et al. (2006) found that $92 \%$ of newly formed roots developed on the distal pole, $5.5 \%$ on the proximal pole and $2.3 \%$ in the center of the RSC. Ky-Dembélé et al. (2010) observed on Detarium macrocarpum that leafy shoots formed preferentially on the proximal pole. The location of the 
leafy shoots formation is apparently species specific. Based on this information further work shall assess the effect of RSC position (horizontal, vertical and slant) in the rooting medium on leafy shoots and roots formation.

The "superiority" of the 1.1-2.5 cm diameter RSC compared to the $0.5-1 \mathrm{~cm}$ diameter RSC was most likely because of the greater availability of nutrients, including carbohydrates, in the former than in the latter. The RSC diameter determines the amount of nutrients and the availability of carbohydrates in the cutting. Similarly, the season of harvesting could also influence the amount of nutrients and carbohydrates in the cutting. It is for this reason that the RSC were harvested shortly before the end of the dry season. Heller (1985) cit. Sanoussi et al. (2012) argues that the carbohydrate content is high in the roots during the rainy season, but these reserves are transported to the collar or the surface roots at the beginning of periods of stress such as the dry season (Stenvall et al., 2009). The follow up of RSC plants transferred to the field since 2012 shown that no plant has flowed yet.

\section{Conclusion}

This study demonstrated that $V$. doniana can be very easily propagated from RSC harvested in February (i.e. near the end of the dry season). The diameter of the RSC is an important factor that influences the formation of leafy shoots and adventitious roots.

For future work, it is planned to evaluate the effects of (i) the harvest season of the RSC (beginning of the dry season vs. end of the dry season), (ii) the horizontal vs. vertical or slant positioning of RSC in the substrate, and (iii) the length of the cuttings, on the ability to form new leafy shoots and a dense root system. Possibly, tests with growth substances could be undertaken to improve the success rate, but this will lead away from the main objective of this research, which is the development of a low cost vegetative propagation technic that is simple, accessible and sustainable.

Likewise, it will be judicious to analyze the survival of the RSC after two or three years from planting and observe how the root system develops further on the planted RSC.

\section{Acknowledgments}

The authors wish to express their gratitude to the anonymous reviewers for invaluable comments and inputs on the manuscript.

\section{Bibliographical references}

Adetoro K. O., Bolanle J. D., Abdullahi S. B., Ahmed O. A., 2013. In vivo antioxidant effect of aqueous root bark, stem bark and leaves extracts of Vitex doniana in $\mathrm{CCl}_{4}$ induced liver damage rats. Asian Pacific Journal of Tropical Biomedicine, 3 (5): 395-400.
Ajenifujah-Solebo S. O., Aina J. O., 2011. Physico-chemical properties and sensory evaluation of jam made from black-plum fruit (Vitex doniana). African Journal of Food, Agriculture, Nutrition and Development, 11 (3): 4772-4784.

Amegbor K., Metowogo K., Eklu-Gadegbeku K., Agbonon A., Aklikokou K.A., Napo-Koura G., et al., 2012. Preliminary evaluation of the wound healing effect of Vitex doniana sweet (Verbenaceae) in mice. African Journal of Traditional, Complementary and Alternative Medicines, 9 (4): 584-590.

Bellefontaine R., 2005. Pour de nombreux ligneux, la reproduction sexuée n'est pas la seule voie : analyse de 875 cas - Texte introductif, tableau et bibliographie. Sécheresse $16(4): 315-317$.

Bellefontaine R., 2010. De la domestication à l'amélioration variétale de l'arganier (Argania spinosa L. Skeels) ? Sécheresse, 21 (1): 42-53.

Beyl C. A., 2008. Adventitious shoot and root formation on leaf and root cuttings. In: Beyl and Trigiano (Ed.), Plant propagation - Concepts and laboratory exercises. CRC Press, $p$. 233-244.

da Costa C. T., de Almeida M. R., Ruedell C. M., Schwambach J., Maraschin F. S., Fett-Neto A. G., 2013. When stress and development go hand in hand: main hormonal controls of adventitious rooting in cutting. Frontiers in Plant Science, 4: 1-19.

Dadjo C., Assogbadjo A. E., Fandohan B., Glèlè Kakaï R., Chakeredza S., Dèhouégnon Houehanou T., et al., 2012. Uses and management of black plum (Vitex doniana Sweet) in Southern Benin. Fruits, 67 (4): 239-248. http://www.fruitsjournal.org/articles/fruits/pdf/2012/04/fruits120017.pdf

Harivel A., Bellefontaine R., Boly 0., 2006. Aptitude à la multiplication végétative de huit espèces forestières d'intérêt au Burkina Faso. Bois et Forêts des Tropiques, 288 (2) : 39-50. http://bft.cirad.fr/cd/BFT_288_39-50.pdf

Ibrahima A., Mapongmetsem P. M., Hassan M., 2006. Influence de quelques facteurs zoo-anthropiques sur la phytodiversité ligneuse des savanes soudano-guinéennes de l'Adamaoua, Cameroun. Annales de la Faculté des Sciences, Université de Yaoundé I, série Sciences de la Nature et de la Vie, 36 (3): 65-85.

Kranjac-Berisavljevic G., Gandaa B. Z., 2013. Importance of bush grape (Vitex spp.) as food and medicinal plant to the Dagarti speaking people of the Upper West Region of Northern Ghana. Acta Horticulturae, 979: 669-673.

Kristensen M., Lykke A. M., 2003. Informant-based valuation of use and conservation preferences of savanna trees in Burkina Faso. Economic Botany, 57 (2): 203-217.

Ky-Dembélé C., Tigabu M., Bayala J., Savadogo P., Boussim I. J., Oden P. C., 2010. Clonal propagation of Detarium microcarpum from root cuttings. Silva Fennica, 44 (5): 775-787.

Leakey R. R. B., Mesen J. F., Tchoundjeu Z., Longman K. A., Dick J. McP., Newton A., Matin A., Grace J., et al., 1990. Low technology techniques for the vegetative propagation of tropical trees. Comweath Forest Review, 69 (3): 247-257.

Letouzey R., 1968. Étude phytogéographique du Cameroun. Éd. Le Chevalier, Paris, 551 p. 
Mapongmetsem P. M., Kapchie V. N., Tefempa B. H., 2012 a. Diversity of local fruit trees and their contribution in sustaining the rural livelihood in the northern Cameroon. Ethiopian Journal of Environmental Studies and Management, 5 (1): 32-46.

Mapongmetsem P. M., Djoumessi M., Yemele Tonleu M., Fawa G., Doumara G., Noubissie Tchiagam J. B., et al., 2012b. Domestication de Vitex doniana : effet du substrat, de la stimulation hormonale et de la position du nœud sur l'enracinement. JEID (Journal d'Agriculture et d'Environnement pour le Développement International), 10 (1): 23-45.

Mapongmetsem P. M., Hamawa Y., Djeumene P., Maissele D., Kossebe C. F., Ndoum J. F., et al., 2008. Valorisation des plantes alimentaires sauvages dans les savanes soudanoguinéennes du Cameroun. In: Kapseu C., Mbofung C. M. et Amvam Zollo P.H. (Eds). Développement de l'agro-industrie et création des richesses. Actes du Colloque International, Ngaoundéré, Cameroun, p. 50-61.

Meunier Q., Bellefontaine R., Boffa J. M., Bitahwa N., 2006. Low-cost vegetative propagation of trees and shrubs. Technical Handbook for Ugandan Rural Communities. Ed. Angel Agencies, Kampala and CIRAD, Montpellier, 66 p.

Meunier Q., Arbonnier M., Morin A., Bellefontaine R., 2008. Trees, shrubs and climbers valued by rural communities in Western Uganda. Utilisation and propagation potential. French Embassy in Uganda. CIRAD, Montpellier, France, 106 p.

N'danikou S., Achigan-Dako E. G., Wong J. L. G., 2011. Eliciting local values of wild edible plants in southern Benin to identify priority species for conservation. Economic Botany, 65 (4): 381-385.

Njidda A. A., 2012. In situ degradability of dry matter and neutral-detergent fibre of Vitex species as fodder for ruminants in semi arid Northern Nigeria. Journal of Agriculture, Biotechnology and Ecology, 5 (1): 84-96.

Ning D., Renqing W., Jian L., Xiuru Z., Xiangfeng T., Wei W., et al., 2013. Morphological response of Vitex negundo var. heterophylla and Ziziphus jujuba var. spinosa to the combined impact of drought and shade. Agroforestry Systems, 87 (2): 403-416.

Nsibi R., Souayah N., Khouja M. L., Khaldi A., Rejeb M. N., Bouzid S., 2003. Le drageonnement expérimental du chêne liège (Quercus suber L., Fagaceae). Effets de l'âge et des conditions de culture. Geo-Eco-Trop, 27 (1-2): 29-32.

Ochieng C. O., Ishola I. O., Opiyo S. A., Manguro L. A. O., Owuor P. O., Wong Keng C., 2013. Phytoecdysteroids from the stem bark of Vitex doniana and their anti-inflammatory effects. Planta Medica, 79 (1): 52-59.

Okafor J. C., 1991. Amélioration des essences forestières donnant des produits comestibles. Unasylva, 165: 83-96.

Oladele 0. I., 2011. Contribution of indigenous vegetables and fruits to poverty alleviation in Oyo State, Nigeria. Journal of Human Ecology, 34 (1): 1-6.

Ouattara A., Coulibaly A., Adima A. A., Ouattara K., 2013. Exploration of the antistaphylococcic activity of Vitex doniana (Verbenaceae) stem bark extracts. Academic Journal of Pharmacy, 2 (2): 94-100.
Ouedraogo A., Thiombiano A., 2012. Regeneration pattern of four threatened tree species in Sudanian savannas of Burkina Faso. Agroforestry Systems, 86 (1): 35-48.

Oumorou M., Sinadouwirou T., Kiki M., Kakai R. G., Mensah G. A., Sinsin B., 2010. Disturbance and population structure of Vitex doniana Sw. in northern Benin, West Africa. International Journal of Biological and Chemical Sciences, 4 (3). http://dx.doi.org/10.4314\%2Fijbcs.v4i3.60467

Ruchala S. L., 2002. Propagation of several native ornamental plants. Electronic Theses and Dissertations, Univ. Maine, 115 p. http://digitalcommons.library.umaine.edu/etd/448

Sanogo R., Karadji Avarga Halimatou H., Dembele O., Diallo R., 2009. Activité diurétique et sadiurétique d'une recette en médecine traditionnelle pour le traitement de l'hypertension artérielle. Mali Médical, 23 (4) : 1-6.

Sanoussi A., Ahoton L. E., Odjo T., 2012. Propagation of Black Plum (Vitex donania Sweet) Using Stem and Root Cuttings in the Ecological Conditions of South Benin. Tropicultura, 30 (2): 107-112.

Silva D. B., Vieira R. F., Cordeiro M. C. T., Pereira E. B. C., Pereira A. V., 2011. Propagação vegetativa de Brosimum gaudichaudii Tréc. (mama-cadela) por estacas de raízes. Revista Brasileira de Plantas Medicinais, 13 (2): 151-156.

Stenvall N., Haapala T., Aarlahti S., Pulkkinen P., 2005. The effect of soil temperature and light on sprouting and rooting of root cuttings of hybrid aspen clones. Canadian Journal of Forest Research, 35: 2671-2678.

Stenvall N., Haapala T., Pulkkinen P., 2006. The role of a root cutting's diameter and location on the regeneration ability of hybrid aspen. Forest Ecology and Management, 237: 150-155.

Stenvall N., Piisilä M., Pulkkinen P., 2009. Seasonal fluctuation of root carbonhydrates in hybrid aspen clones and its relationship to the sprouting efficiency of root cuttings. Canadian Journal of Forest Research, 39: 1531-1537.

Suleiman M. M., Yusuf S., 2008. Antidiarrheal activity of the fruits of Vitex doniana in laboratory animals. Pharmaceutical biology, 46 (6): 387-392.

Tchiegang-Megueni C., Mapongmetsem P. M., Akagou Zedong C. H., Kapseu C., 2001. An ethnobotanical study of indigenous fruit trees in Northern Cameroon. Forests, Trees and Livelihoods, 11 (2): 149-158.

Thies E., 1995. Principaux ligneux (agro)-forestiers de la Guinée - Zone de transition. Schriftenreihe der GTZ n 253 (Deutsche Gesellschaft für Technische Zusammenarbeit), Eschborn, Germany, 544 p.

Tijjani M. A., Abdurahaman F. I., Khan I. Z., Sandabe U. K., 2012. The effects of ethanolic extract of Vitex doniana stem bark on peripheral and central nervous system of laborotory animals. Journal of Applied Pharmaceutical Science, 2 (3): 74-79.

Wala K., Guelly A. K., Batawila K., Dourma M., Sinsin B., Akpagana K., 2009. Traditional agroforestry systems in Togo: variability according to latitude and local communities. IUFRO World Series, 23: 21-27. 